\title{
New Pathways of Sociopolitical Complexity in Southern Africa
}

\author{
Shadreck Chirikure ${ }^{\star}$ Munyaradzi Manyanga • Innocent Pikirayi • Mark \\ Pollard
}

\begin{abstract}
Much is known about the economy and spatial organization of Zimbabwe culture entities of Mapungubwe, Great Zimbabwe and Khami but less in terms of their origins and relationship with each other. Based on little tangible evidence, it is believed and widely accepted that the societies based at Mapungubwe (AD 1220-1290), Great Zimbabwe (AD 1300-1450) and Khami (AD 1450-1820) rose, developed and eclipsed in tandem. A recent reexamination of the relationship between these settlements and related ones using local ceramics, imported artefacts, stone architecture and Bayesian modelling suggests this may not have been the case. The synthesis proffered revelations which temper the widely accepted assumption that sociopolitical complexity in southern Africa began in the Shashi-Limpopo Valley before anywhere else in the region. Firstly, there are numerous Zhizo and Leopard's Kopje sites that predate Mapungubwe but contain prestige goods and stone structures dating from the late first millennium AD. Secondly, material culture studies and modelled radiocarbon dates indicate that Great Zimbabwe evolved out of Gumanye while Khami, like Mapungubwe, may have developed out of the Leopard's Kopje. In fact, Great Zimbabwe was already a place of importance when Mapungubwe collapsed. Thirdly, Khami and Great Zimbabwe overlapped for over a century, before the latter buckled. Therefore, the evolution of sociopolitical complexity in southern Africa may have followed trajectories that are different from what the current understanding implies.
\end{abstract}

Résumé Nous savons beaucoup de choses à propos de l'organisation spatiale et de l'économie des entités culturelles Zimbabwéennes de Mapungubwe, Great Zimbabwe et Khami, mais peu sur leurs origines et leurs relations. Selon le peu de données disponibles, Mapungubwe (1220-1290 ap. J-C), Great Zimbabwe (1300-1450 ap. J-C) et Khami

S. Chirikure $\left(^{*}\right) \cdot$ M. Manyanga Cape Town, South Africa e-mail: shadreck.chirikure@uct.ac.za

\author{
I. Pikirayi \\ University of Pretoria, Pretoria, South Africa \\ M. Pollard \\ Oxford University, Oxford, United Kingdom
}


(1450-1820 ap. J-C) auraient été fondés, se seraient développés et se seraient effondrés successivement. De récentes recherches ont exploré les relations entre ces différents sites ainsi que ceux qui y sont rattachés, en étudiant les céramiques locales, les objets importés, la typologie des murs de pierres et notamment les préférences résidentielles, et la modélisation Bayesienne. La synthèse permet de tempérer la vision dominante selon laquelle la complexité sociopolitique dans le Sud de l'Afrique a commencé dans la vallée du Shashi-Limpopo, avant tout autre site dans la région. Tout d'abord, il y a de nombreux sites antérieurs à Mapungubwe, Zhizo et Leopard's Kopje, avec des biens de prestige et des fortifications en pierre datant de la fin du premier millénaire ap. J-C. Ces caractéristiques seraient apparus à K2 et Mapungubwe dans la dépression du Limpopo. Deuxièmement, la culture matérielle et les datations carbones indiquent que Great Zimbabwe était déjà un lieu important quand Mapungubwe s'est effondré. Enfin, Khami et Great Zimbabwe coexistent pendant plus d'un siècle, avant que ce dernier ne tombe en déchéance. Par conséquent, la complexité sociopolitique dans le Sud de l'Afrique a probablement emprunté des trajectoires différentes de celles qui sont actuellement tracées avec les connaissances disponibles.

Keywords Zimbabwe culture · Sociopolitical complexity · Southern Africa · Great Zimbabwe $\cdot$ Khami $\cdot$ Mapungubwe

\section{Introduction}

The Zimbabwe culture, famous for its dry-stone-built capitals, is arguably one of the most important cultural developments in the last two millennia of sub-Saharan prehistory/history (MacIver 1906; Caton-Thompson 1931; Garlake 1973; Robinson 1985; Sinclair 1987; Pwiti 1996; Pikirayi 2001; Huffman 2007; Kim and Kusimba 2008). Three former capitals, Great Zimbabwe, Khami and Mapungubwe, are all UNESCO World Heritage Sites. For a very long time, the culture has attracted the awe of foreign observers such that when Karl Mauch reported it to the outside world in 1871, amateur and academic archaeologists engaged with Great Zimbabwe and associated places in mesmeric detail (Bent 1896; Hall and Neal 1902; MacIver 1906; Caton-Thompson 1931; Summers et al. 1961; Hall 1987; Huffman 1996; Beach 1998; Pikirayi 2001; Kim and Kusimba 2008; Chirikure et al. 2012). However, most of this took place without the participation of local scholars and communities, resulting in an archaeology that is incompatible with local understandings and expectations (Garlake 1982; Pwiti 1996; Kusimba 2006; Chirikure and Pikirayi 2008). Fontein (2006) deplored the championing of singular interpretations at Great Zimbabwe which marginalised alternative and subaltern voices. This tendency, argues Fontein, also pushed local myths, legends and histories into the abyss, resulting in a poorer past.

Expressing his frustration at how the archaeology of the Zimbabwe culture marginalised local people and their narratives from the mainstream, Garlake (1982:3) cogently argued that "the settler paradigm has governed all protohistoric research in Zimbabwe even though archaeologists all recognized the absurdity of the settler view on the origins of Great Zimbabwe." The settler paradigm held that Great Zimbabwe and related sites were built by exotic people since local peoples were incapable of making such achievements (Bent 1896). Cultural change was explained in terms of domination and migration against a background of passive African communities. Garlake called upon local scholars to enter the 
fray to temper some of the assumptions emanating from the colonial ancestry of Zimbabwe culture studies. So far, few local scholars have taken up this challenge (Pikirayi 2001; Kusimba 2006; Kim and Kusimba 2008; Chirikure et al. 2012) despite the fact that researchers such as Hall (2009), Schmidt (2009) and Lane (2011) have fervently advocated for a postcolonial archaeology that is simultaneously multivocal and locally empowering.

The main topics that dominated research on the Zimbabwe culture during the past century include the origins and identity of the societies attributed to the construction of monumental architecture (MacIver 1906; Caton-Thompson 1931), dating and chronology (Summers et al. 1961; Garlake 1973; Huffman and Vogel 1991; Chirikure et al. 2013), material culture identities (Schofield 1937; Robinson 1961b; Pikirayi 1993; Pwiti 1996), migrations as the prime mover of cultural change (Schofield 1937; Jaffey 1966; Huffman 1982), divine kingship (Jaffey 1966; Huffman 1982), and spatial organization and ritual and symbolic meaning (Huffman 1982, 2007). A central thread that runs through some of the earliest works was the idea that domination and population replacement were engines for cultural change. For example, according to Schofield (1937), "the pottery of Zimbabwe III [Great Zimbabwe] was similar to class MI at Mapungubwe, indicating perhaps that the latter came within the sphere of Zimbabwe III about the fourteenth or fifteenth century" (own emphasis). The legacy of this view is that although the argument was flipped by Huffman $(1982,2000,2009)$ to make Great Zimbabwe fall under the state of Mapungubwe in the thirteenth century, the basic idea is still that of the domination of southern Africa by a single entity at a time. Thus, Garlake (1982:6) observed that even though new concepts were introduced to the study of the Zimbabwe culture particularly in the 1980s, the basic paradigm remained entirely unchanged going back through Summers, Robinson and Schofield, in that little attention was given to smaller sites while internally generated change was downplayed in explaining major cultural changes.

Not surprisingly, the beginning of sociopolitical complexity is reduced to one point on the landscape - the Shashi-Limpopo confluence area - where, purportedly, ideological transitions associated with class distinction were nurtured before being materialized on Mapungubwe Hill (Huffman 1982, 2009). Indeed, Mapungubwe is assumed to represent the earliest palace which is spatially organized like Great Zimbabwe and other settlements that came after (Sinclair 1987; Huffman and Vogel 1991; Huffman 1996; Pikirayi 2001). Furthermore, long-distance trade is often seen as a catalyst that provided the means to create social inequalities (Pwiti 1991). This is the widely accepted view but has never been scrutinized using multiple strands of evidence and a local point of view as advocated by Garlake (1982). Although ideology may have been important, it is not clear how the elites managed to impose their power over large tracts of land. Recently, Kusimba (2006) and Kim and Kusimba (2008) have passed useful comment on the role of warfare and coercion, factors that - despite historically promoting state formation in southern Zambezia (Beach 1980; Mudenge 1988, Pikirayi 2001) - have been marginalised in the study of the emergence of sociopolitical complexity in southern Africa. The significance of warfare and coercion is that as with all other local factors, they force researchers to move away from a preoccupation with the question of why sociopolitical complexity emerged, to considering how the process might have unfolded, thereby considering a series of related sites on the landscape and not just the biggest ones.

In this milieu, we present our study, which is based on three core pillars: (1) a review of the ceramic evidence, (2) a reexamination of the stone architecture and (3) Bayesian modelling of radiocarbon dates. It aims to reexamine the material culture and chronology 


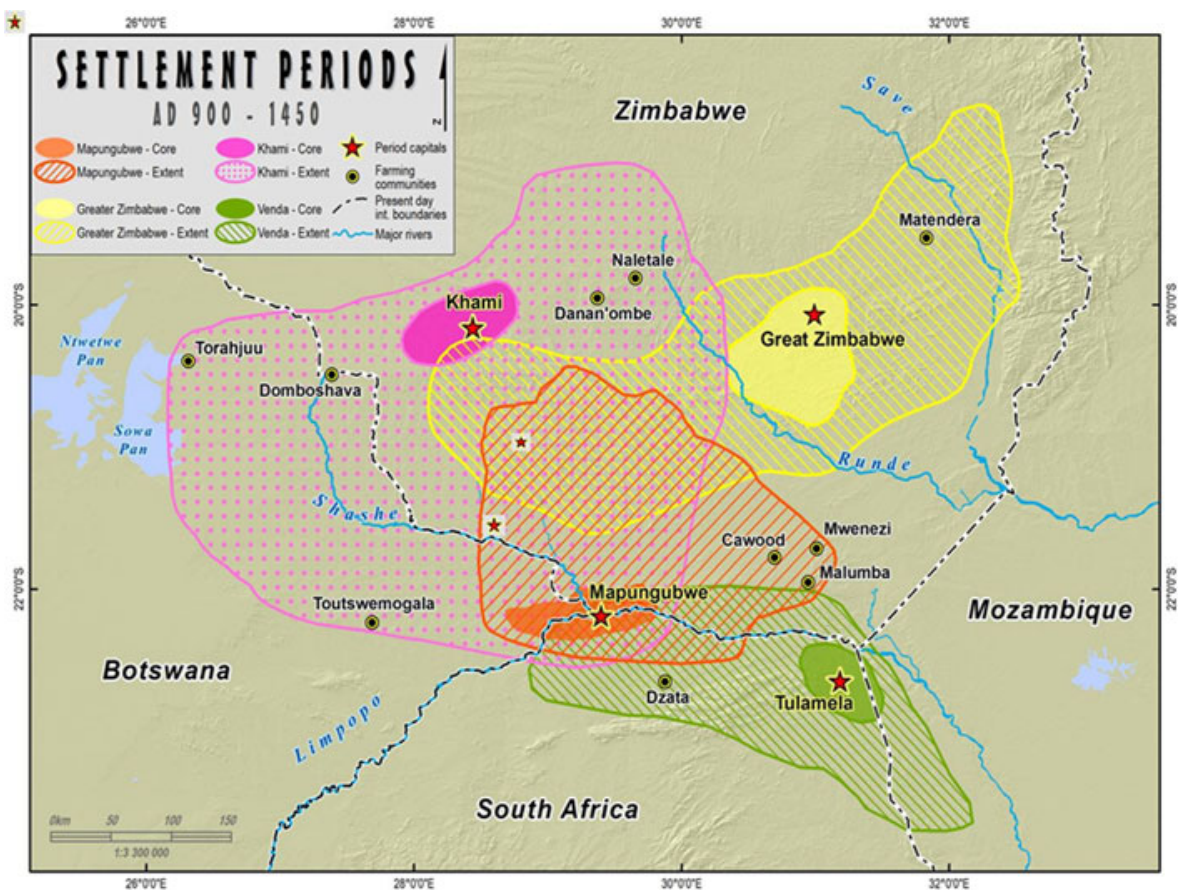

Fig. 1 Map of southern Africa showing the location of some elite sites and approximate boundaries of the states of Mapungubwe, Great Zimbabwe, Khami and Venda as implied in published works

of the archaeological sites dating between the late first and early second millennium $\mathrm{AD}$ in southern Africa, to shed new light on the beginning of sociopolitical complexity in the region (Fig. 1). The results indicate the existence of numerous sites dating from the late first millennium $\mathrm{AD}$ that intimate the presence of sociopolitically complex communities. It was also demonstrated that Great Zimbabwe developed out of Gumanye (see also Sinclair 1987), while the material culture from the basal levels of the stone-walled area at Khami (see Robinson 1959) indicates that it probably developed from the Leopard's Kopje tradition. This establishes a relationship between Khami and Mapungubwe showing they were founded by Kalanga (a sub-branch of Shona) speakers, as widely acknowledged (Huffman 2007). Our understanding of the emergence of sociopolitical complexity is likely to change further if research is directed to archaeological sites such as Mapela and Jahunda that have yet to receive detailed attention. Ongoing research on the Leopard's Kopje levels at Jahunda has dated high-tin bronzes to the early twelfth century $\mathrm{AD}$ (Chirikure et al., in preparation). Because bronze is regarded as an elite metal (Killick 2009), its appearance at Jahunda almost a century before at Mapungubwe may indicate the presence of other important places on the landscape that require research attention.

\section{A Historiography of the Zimbabwe Culture}

Since the first research encounters with the Zimbabwe culture, the topics of investigation and resulting interpretations have shifted with time (Hall 1990; Pikirayi 2001). During the late nineteenth and early twentieth centuries, Great Zimbabwe was seen as 
a remnant of Hamitic, Semitic or Phoenician occupation (Bent 1896; Hall and Neal 1902). In a bid to demonstrate this exotic origin, Richard Hall caused extensive damage at Great Zimbabwe, throwing away material culture, primarily local, that was inconsistent with his desired exotic interpretation. So harmful were his methods that a professional archaeologist, MacIver (1906), was invited to excavate Great Zimbabwe to solve the origins issue. MacIver concluded that Great Zimbabwe was medieval in date and thus local in origin. Due to strong beliefs in African incapacity, and a lack of absolute methods of dating, the settlers resisted MacIver's findings (Garlake 1982; Hall 1987). Caton-Thompson (1931), an expert archaeologist who had excavated in Egypt, investigated Great Zimbabwe and related sites and deduced that they were local in origin. CatonThompson also noted that it was virtually impossible to interpret the Zimbabwe culture without making recourse to local history. Ever since, every archaeologist has taken up this advice, but the failure to engage historians lamentably has resulted in an improper and almost perfunctory use of historical information (Beach 1998).

In the early 1930s, the site of Mapungubwe situated near the confluence of the Limpopo and Shashi rivers was brought to the attention of the world (Fouché 1937; Gardner 1955, 1963). What made Mapungubwe famous was the recovery of gold-rich burials that enchanted professionals and amateurs alike (Fouché 1937). Further research around Mapungubwe uncovered a large mound at the site of Bambandyanalo, more widely known as K2 (Gardner 1963). As it turned out, K2 was rich in burials with significant amounts of accompanying grave goods. Because it was smaller than Great Zimbabwe, Mapungubwe was seen as an extension of the former (Fouché 1937). Van Riet Lowe (1936) and CatonThompson (1939), however, noted significant differences between the ceramics, stone walling and other material culture of Mapungubwe and Great Zimbabwe.

In the late 1950s, Roger Summers, Keith Robinson and Antony Whitty commenced an interdisciplinary study of Great Zimbabwe in an effort to correlate artefact types to the stratigraphy, as well as to build a chronology of the stone walls (Summers et al. 1961). Samples of carbonaceous materials were submitted for dating using the newly developed radiocarbon technique. While Robinson (1961a) concentrated on the Hill Complex, Summers and Whitty (1961) focused on the Great Enclosure. Their work represents the most detailed professional archaeological work ever carried out at Great Zimbabwe and is the source of most primary data relating to the site. Robinson (1961b, c) analysed local ceramics and exotic beads recovered from Great Zimbabwe. The material culture evidence was combined with architectural information, stratigraphic details and radiocarbon dates to define a five-phase sequence of occupation at the site (Summers et al. 1961). Period I (AD 100-300) was characterised by the presence of class I pottery, while period II and its class 2 pottery dated between AD 300 and 1085. Period III, defined on the basis of class 3 pottery and P-style walling (earliest walling with no clear courses), flourished between AD 1085 and 1450. On its part, period IV and the associated class 4 pottery and Q-style (neatly coursed) walling lasted from AD 1450 until 1833. Finally, period V (AD 1833-1900), characterised by class 5 pottery and R (rough) walling, was the youngest. Periods II to V were associated with the Karanga branch of the Shona speakers (Summers et al. 1961). Using imports, Garlake (1973) argued that the main occupation at Great Zimbabwe dated between AD 1200 and 1450.

Robinson (1959) carried out detailed excavations in southwestern Zimbabwe focusing on Khami and numerous Leopard's Kopje sites. His work remains the most detailed archaeological research ever carried out in the area. The Khami excavations generated 
local ceramics characterised by bands and panels of graphite and red ochre and many others. Some beakers with close affinities to those from Mapungubwe and other Leopard's Kopje sites were recovered. Furthermore, a significant number of imports that include various types of glass beads were recovered as well. Robinson (1959:147) noted that his group I beads from the basal levels corresponded closely to the bedrock series (K2/Mapungubwe types) at Great Zimbabwe. Because of a stratigraphic break between Leopard's Kopje layers and a Khami occupation in one of his trenches, Robinson believed that the two were unrelated. However, Robinson (1965) excavated a deposit showing a direct succession from Woolandale (phase II Leopard's Kopje) and Khami pottery at Taba Zika Mambo. Stylistically, Woolandale has graphite burnishing to red slipping just as at Khami. A careful study of Leopard's Kopje and Khami ceramics, however, reveals that Khami is more closely related to Woolandale and Mapungubwe (phase II) than to Mambo and K2 (phase I Leopard's Kopje). Like other researchers, Robinson focussed more on the material he believed to postdate AD 1450, when Great Zimbabwe was believed to have declined. It was widely believed that Khami was an offshoot of Great Zimbabwe because it had Portuguese-period imports. And yet, a careful examination of Robinson (1959) shows that the basal levels in the stone-built area contained black opaque glass beads and other material culture comparable to that of Mapungubwe and other places. Had attention been directed at these deposits, the place of Khami in the beginning of complexity in southern Africa would have shifted long ago.

Across the Limpopo, archaeological work continued at Mapungubwe and K2 in a context where ideas of African incapacity were rife (Hall 1990). Physical anthropological evidence ostensibly suggested that the human skeletons from K2 and Mapungubwe were Boskopoid and not Bantu (Galloway 1963). As the excavations unfolded, attempts were made to forge a relationship between Mapungubwe and Great Zimbabwe (see for example, Schofield 1937). Because Great Zimbabwe was the biggest, it was seen as the progenitor of the Zimbabwe culture, such that Mapungubwe was believed to be a manifestation of the extent of Great Zimbabwe's influence (Fouché 1937; Garlake 1973). The dating of carbonized seeds from Mapungubwe, however, produced dates from the fourteenth and fifteenth centuries AD (Hall and Vogel 1980), which made the site younger than Great Zimbabwe. These dates from Mapungubwe were later rejected on technical grounds.

Huffman (1978) argued for what he called the early second-millennium AD Kutama tradition associated with ceramic clusters known at the time. This tradition was a result of a northward migration of ancestral Shona speakers from the south (Huffman 1978). It consisted of four facies or geographical entities - Leopard's Kopje, Gumanye, Harare and Musengezi. The Leopard's Kopje is associated with western Shona (Kalanga) who resided in northeastern Botswana, southwestern Zimbabwe and adjacent areas of northern South Africa, while Gumanye is linked to early Karanga (central Shona) settlement mostly concentrated in south-central Zimbabwe. Harare and Musengezi are respectively associated with Zezuru and Korekore speakers of northern Zimbabwe.

Huffman (1982) used cognitive structuralist theories to reinterpret data from Great Zimbabwe and Mapungubwe, arguing that the latter was an offshoot from the former. This argument is clearly along the lines which Schofield (1937) and others had suggested. By combining selected ethnographic evidence with a reading of ideologies associated with settlement organization, it was argued that early in the second millennium AD, ideological transformations occurred at $\mathrm{K} 2$, resulting in the removal of cattle from the centre, and putting an end to the Central Cattle Pattern (CCP). The CCP is an ethnographically derived model to 
interpret spatial organization of southern African Sotho-Tswana and Nguni settlements (Kuper 1982), popularised by Huffman (1982, 1996, 2007). It states that houses in Iron Age settlements formed a horseshoe around a central kraal, and were organized by seniority such that authority and politics could be read from settlement layout. Subsequently, settlement was thought to have shifted to the nearby settlement of Mapungubwe. The hilltop occupation of Mapungubwe, when contrasted with that of the low-lying southern terrace, materialized the ideology of sacred leadership and class distinction early in the thirteenth century (Huffman 1982). This initiated what is now known as the elite Zimbabwe Pattern (also ethnographically derived, associated with a palace of the king, residence for royal wives, public court and a place for guards, with cattle no longer at the centre; Huffman 1982, 1996, 2007). According to Huffman (1982, 2009), this ideological transition marks the beginning of sociopolitical complexity in southern Africa. It is also associated with political centralization and the emergence of Mapungubwe as an influential capital. The use of space at Mapungubwe was identical to that at Great Zimbabwe and its successors, but because Mapungubwe was the earliest, it was considered the birthplace of the Zimbabwe culture. This is regardless of the fact that outwardly, Mapungubwe and Great Zimbabwe have little in common (Van Riet Lowe 1936; Caton-Thompson 1939; Robinson 1961b).

Huffman and Vogel (1991) redated Great Zimbabwe and revised Summers et al.'s (1961) long chronology to 150 years. They argued that stone walling, believed by Robinson (1961a) to have started in the early thirteenth century, began after AD 1300 when Mapungubwe collapsed. The main problem with Huffman and Vogel's revised chronology, as pointed by Chirikure et al. (2013), is that to factor in the effect of the oceans on the level of radiocarbon in the atmosphere, they subtracted plus or minus 20 years from calibrated dates as a correction procedure. Nowadays, such computations are unnecessary, for southern hemisphere calibration has improved significantly (see McCormac et al. 2004). A recent Bayesian modelling of the radiocarbon dates from Great Zimbabwe, using the widely accepted southern hemisphere curve, demonstrated that the site overlapped with Mapungubwe for over a century while lasting until the sixteenth century (Chirikure et al. 2013). This is supported further by the combined dating and material culture evidence, which suggests that Great Zimbabwe was already an important place during K2 times (see Robinson 1961c; Wood 2011; Chirikure et al. 2012).

Although various archaeologists such as Pwiti (1991, 1996), Garlake (1978) and Pikirayi (2001) have argued for the importance of local factors such as cattle and religion in the development of sociopolitical complexity, today the most commonly held assumptions about the Zimbabwe culture are as follows: (1) K2 and Mapungubwe are the origins of regional sociopolitical complexity (Huffman 1982, 1996, 2000, 2009), (2) sociopolitical complexity is only defined on the basis of class distinction (i.e., the physical separation of the rulers from the ruled), (3) the spatial organization at Zimbabwe culture places was one and the same (Huffman 1982, 1996, 2009) and (4) Mapungubwe (AD 1220-1290) is the first Zimbabwe culture state, which was succeeded by Great Zimbabwe (AD 1300-1450) and in turn followed by Khami (AD 1450-1820) (Huffman 2000, 2009). Unequivocally, this suggests that the rise and fall of these places occurred in tandem. Not surprisingly, Mapungubwe was nominated for the World Heritage List on the basis that it was the first Zimbabwe culture state and capital (DEAT 2002), one that failed as a result of environmental constraints and resulting in the rise of Great Zimbabwe (see also Huffman 2000 , 2009). Perhaps the only worrisome point here is that this framework is based on limited evidence that not only excluded the basal levels of Khami, but ignored the 
significance of similarities in material culture and presence of prestige goods at many sites dating to the first- and second-millennium $\mathrm{AD}$ interface (Chirikure et al. 2012).

Not surprisingly, researchers familiar with the archaeology of the region that encompasses southern and southwestern Zimbabwe, eastern Botswana and the Limpopo Depression have long expressed their reservations about the validity and appropriateness of this widely held view (Robinson 1965, 1985; Garlake 1982; Hall 1984; Beach 1994, 1998; Chipunza 1994; Manyanga et al. 2000; Lane 2005; Chirikure and Pikirayi 2008; Chirikure et al. 2012). For example, Robinson (1985), who excavated Great Zimbabwe extensively and spent most of his professional life excavating in southwestern Zimbabwe, argued that Huffman's opinions about the beginning of sociopolitical complexity in southern Africa did not accurately reflect the archaeology on the ground. Based on primary evidence, Robinson (1985:32-33) made the point that from the early twelfth century $\mathrm{AD}$, large houses of dhaka (adobe) were built on the hill at Great Zimbabwe. Because they are massive, a command of a large pool of labour would have been required, indicating a high degree of authority on the residents of the Hill Complex. In this case, coercion and force may have enabled the elites to extract labour from commoners, resulting in the rise of sociopolitical complexity in our region (Kim and Kusimba 2008). Thus, Robinson (1985) believes that Great Zimbabwe was already a place of importance long before Mapungubwe's demise at AD 1290. Unlike other researchers whose interpretations are based on secondary evidence, Robinson's observations flowed from primary data - he was in the trenches (see Robinson 1961a, b, c).

Several other scholars have weighed in with useful criticisms of the cognitive structuralism-inspired interpretation, which over the years have enhanced our understanding of the Zimbabwe culture. For example, Lane (1994/1995, 1998, 2005) has pointed out the problems associated with the selective use of ethnographic evidence, which tended to promote singular interpretations of the past while downplaying change. Furthermore, Beach (1998) and Beach et al. (1997) have decried the failure by archaeologists to incorporate more of local history into their interpretations. The most pertinent point here is that even if one were to remove elements of cognitive structuralism from understanding the second millennium $\mathrm{AD}$ in southern Africa, the same historical baseline would remain. Beach (1998) also criticised the lack of rigour in the use of historical information by archaeologists. And yet, some researchers have argued that the distribution of material culture must play an important role in understanding the use of enclosures at places such as Great Zimbabwe (Chirikure and Pikirayi 2008). Such a view encourages the archaeological investigation of lesser known sites to build a vibrant picture supported by observations on the ground. On their part, Kim and Kusimba (2008) have argued that conflict and coercion may have played an important role in the rise of various Zimbabwe culture entities. In a way, this opens up opportunities for works that seek to consider the many sites associated with the beginning and flourishing of urban centres in southern Africa.

Furthermore, research into the archaeology of the Zimbabwe culture has hardly moved away from sites such as Mapungubwe and Great Zimbabwe and has agonisingly ignored other places that are equally important, such as Mapela (Chirikure et al. 2012). Yes, Mapungubwe, Khami and Great Zimbabwe were important, but how did they relate to their little-known contemporaries? The result of this status quo is that some sites have become more important than others only because they are better known archaeologically, a phenomenon not unique to this region. It is therefore important to consider multiple places in the development of new understandings of the evolution of 
sociopolitical complexity in southern Africa. Building on a foundation established by other researchers past and present, this paper advocates the use of multiple strands of evidence - material culture, ideology and radiocarbon dates - to offer fresh and broadbased perspectives on the development of the Zimbabwe culture.

\section{Intrasite Comparisons of Local Ceramics from Zimbabwe Culture Centres}

This section draws from our original research into the Zimbabwe culture ceramics spanning more than a decade. Pikirayi (1993) studied period IV Zimbabwe culture ceramics from northern Zimbabwe in the 1990s. Furthermore, he investigated Khami pottery that is archived at the Pitt Rivers Museum, Oxford. Manyanga et al. (2000) and Manyanga (2001) analysed a large sample of Zhizo and Leopard's Kopje ceramics in the Shashi-Limpopo confluence area, while Chirikure et al. (2001) worked with Khami pottery excavated by MacIver (1906) and by teams led by Caroline Thorp and Gwylum Hughes, respectively. We combine our observations with published accounts by other researchers.

In Iron Age studies in southern Africa, local ceramics have played a significant role in the establishment of culture historical sequences. Ceramic decorative style has been used as a proxy for group identity because a correlation between ceramic style and group identity has been postulated. Huffman (1980) studied the material culture of different ethnographic groups and observed similarities in the repertoire of symbols and designs that appear on varied categories of material culture such as items of dress, stone walls and pottery. In this experimental study, Huffman established that the goodness of fit between ceramic decorative style and group identity was far better than any other types of material culture. Thus, based on his multidimensional typological approach which considers vessel shape, decoration technique, placement and motifs, Huffman argued that this methodology can identify archaeological ceramic groups that can be equated to linguistic groups (Huffman 1974a).

Archaeological work on the Zimbabwe culture ceramics has identified a number of ceramic units that on the basis of radiocarbon dating appeared from the tenth century AD onwards (Robinson 1965). Huffman (1978) defined a Kutama tradition which he identified with ancestral Shona speakers and which he argued was unrelated to the preexisting Zhizo Early Iron Age tradition (see also Huffman 1974b). The Kutama tradition consists of four facies and phases: the Leopard's Kopje, distributed in southwestern Zimbabwe and adjacent regions of Botswana and northern South Africa, being the earliest; Gumanye, distributed in south-central Zimbabwe and seemingly an expansion of the tradition to the Zimbabwe plateau; and the twelfth-sixteenth-century Harare and Musengezi phases found in north-central and northern Zimbabwe (Huffman 1978).

The Leopard's Kopje and Gumanye phases of the Kutama tradition are directly associated with the Zimbabwe culture. The Leopard's Kopje flourished from the late first millennium $\mathrm{AD}$ to the fourteenth century $\mathrm{AD}$ (Robinson 1965). In southwestern Zimbabwe and northeastern Botswana, it is associated with two phases, Mambo and Woolandale, while in the Limpopo Depression it is linked with K2 and Mapungubwe (Robinson 1959, 1965; Huffman 1974b). According to Huffman (1974b:109), Mapungubwe should not be considered as a type site, but only as a member of Leopard's Kopje. In other words, when compared to many other features of the Leopard's Kopje sites, Mapungubwe does not stand 

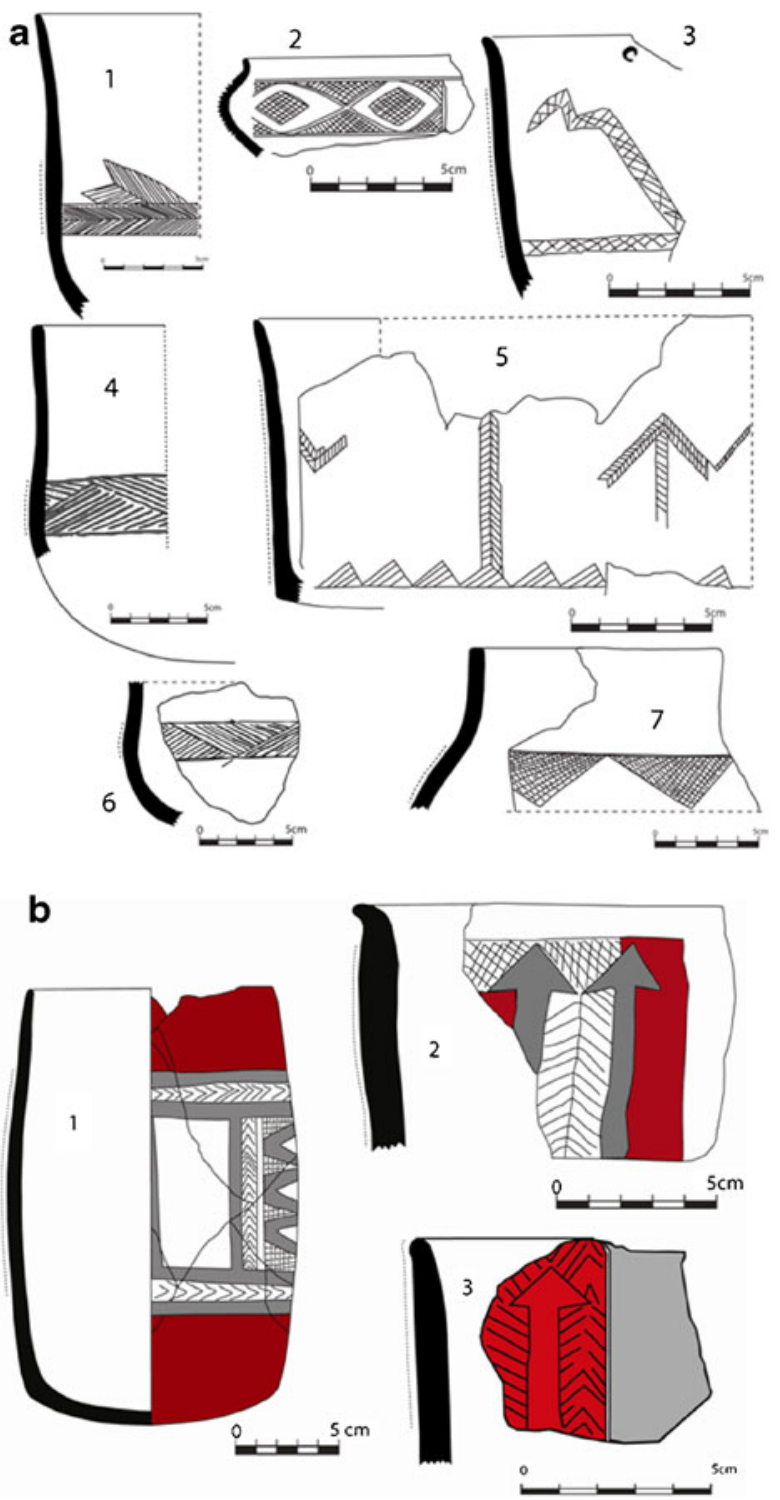

Fig. 2 a Mapungubwe pottery (1-5 after Schofield 1937, 6 after Garlake 1968 and 7 after Manyanga 2001). b Khami pottery (after Robinson 1959, Chirikure et al. 2001 and Pikirayi n.d.)

out as the only one of its kind. The distribution of the Leopard's Kopje in all its phases stretches from Taba Zika Mambo in west-central Zimbabwe to southwestern Zimbabwe, northeastern Botswana and adjacent areas of northern South Africa. This wide area was also home to Khami pottery, which like the Leopard's Kopje, is also associated with Kalanga speakers (Huffman 2007). In terms of designs, Khami pottery is as complex as that from Mapungubwe (see Fig. 2a-b) although it is often characterised by bands and panels of red ochre and graphite. The polychrome designs feature on Woolandale, the Leopard's Kopje phase which lies directly below Khami at Taba Zika Mambo and other places (Robinson 
1965). Although Khami and Leopard's Kopje pottery co-occur at most sites and were all created by Kalanga speakers, the relationship between the two has never been explored in full. This is because Khami has only been considered as a post-Great Zimbabwe entity. However, ceramic evidence indicates unequivocally that there is a relationship between Khami and Leopard's Kopje, an observation also supported by other lines of evidence such as stone architecture and radiocarbon dating (Chirikure et al. 2012).

The Gumanye people (Karanga) occupied much of south-central Zimbabwe and adjacent territories. However, the distribution of Gumanye is poorly understood because research coverage has been biased in favour of areas in close proximity to towns (Sinclair 1987). Gumanye pottery was first recovered at Gumanye Hill in the southern Chivi District, from Chivowa Hill west of Masvingo, and on the hill at Great Zimbabwe (note that Gumanye is also known as Zimbabwe period II pottery; Robinson 1961b). Unlike the lavishly decorated Leopard's Kopje ceramics, Gumanye pottery is plain, with occasional incisions (Fig. 3). Robinson (1961b) suggested that there was a difference in paste between Gumanye and its successor period III pottery (overlapping with Mapungubwe ceramics), although no differences in vessel form and decoration technique were observed. Huffman (2000), like Schofield (1937), suggested a connection between Mapungubwe ceramics and period III pottery and used this as evidence that a Mapungubwe dynasty likely established Great Zimbabwe. However, like period II pots, period III ceramics at Great Zimbabwe were hardly decorated (see also Robinson 1961b; Sinclair 1987; Huffman 2000). This is at variance with the lavishly decorated Mapungubwe and Leopard's Kopje pottery (see Figs. 2a, b and 3). In contrast, Khami pottery inherited the beakers decorated with complex geometrical motifs from Leopard's Kopje I and II. In the absence of petrographic work, the differences in paste between period II and III ceramics noted by Robinson (1961a) at Great Zimbabwe are likely a result of changing clay sources rather than an intrusion of Mapungubwe people. This makes sense if the view that even in cases where periods II and III pottery exist at other places outside Great Zimbabwe, the decoration is consistently absent (Sinclair 1987). Furthermore, even Mapungubwe ceramics were made using fabrics of varying textures from fine to coarse, and yet no intrusion of people has been invoked to explain this difference in raw material selection (Schofield 1937).

The most important observation relating to the distribution and occurrence of Gumanye and Leopard's Kopje is that the latter is invariably geographically and perhaps stratigraphically associated with Khami (e.g., Taba Zika Mambo, Robinson 1965), while the former is always overlain by Zimbabwe pottery (Sinclair 1987). Sites where the Leopard's Kopje and Khami co-occur include Khami itself, Taba Zika Mambo, Mapela and many others. This is hardly surprising given that they were made by Kalanga people (see Huffman 2007) and have a high level of similarity in terms of vessel types, decoration designs and complex geometric motifs. Gumanye pottery was found stratified below period III and IV levels at Great Zimbabwe and other places (Sinclair 1987), while stylistic similarities strengthen the possibility that period III pottery at Great Zimbabwe evolved out of Gumanye (Chirikure et al. 2013).

\section{Stone Walling, Settlement Preferences and Ideology}

Arguably, the most distinctive features of the Zimbabwe culture are the dry-stone-walled enclosures and platforms where elite houses were built (Garlake 1970). Inside the 


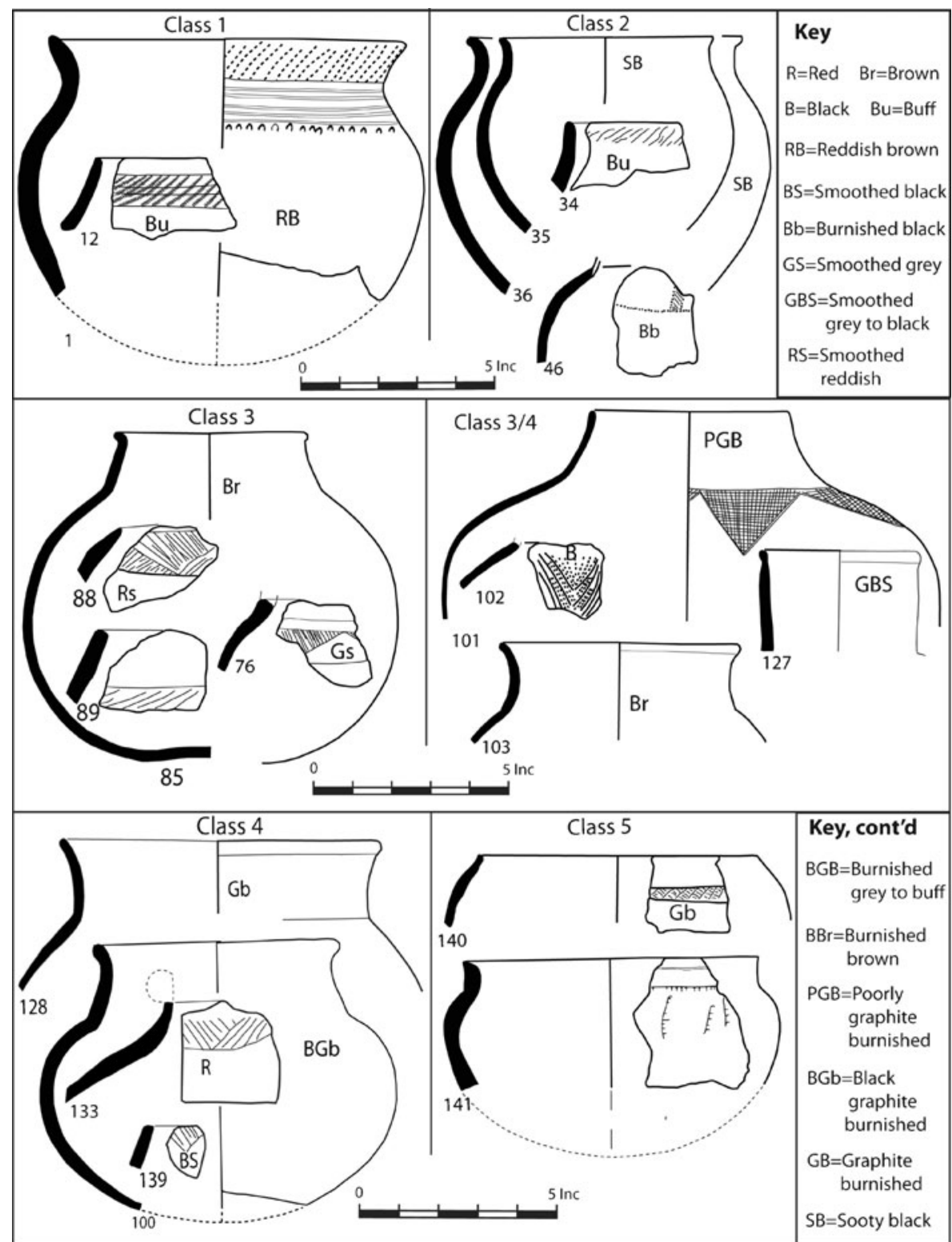

Fig. 3 Local pottery from Great Zimbabwe (after Robinson 1961b). Class 2 overlaps chronologically with $\mathrm{K} 2$, while class 3 is coeval with Mapungubwe

enclosures and on the platforms, houses of solid dhaka or earthen structures were constructed. The raw materials vary from area to area depending on geology, but granite seems to be the most preferred rock type, particularly on the Zimbabwe plateau. The drystone walls of the Zimbabwe culture appear mainly in two forms - terraced walls designed to create platforms for building houses, and freestanding walls that formed 


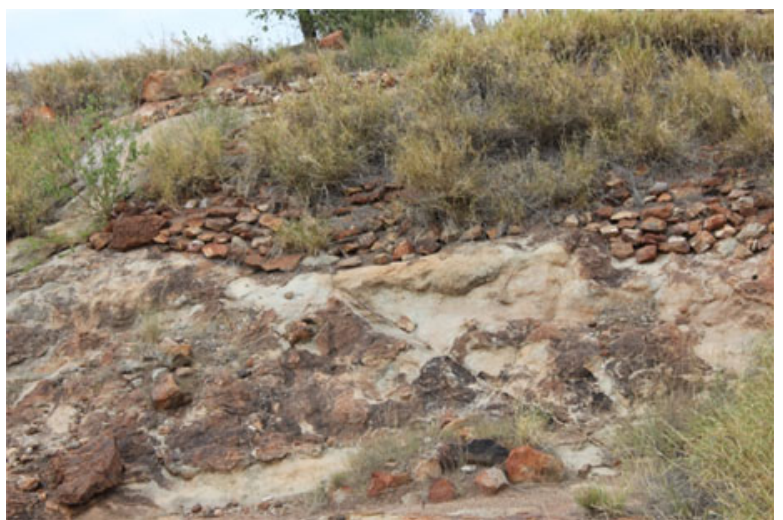

Fig. 4 Retaining walls of the "palace" on top of Mapungubwe Hill (photo: S. Chirikure)

enclosures (Figs. 4, 5, and 6). According to Summers (1965), Khami buildings differ markedly from the freestanding walls of Great Zimbabwe and related sites, in that like those at Mapungubwe, Mapela and other sites, they are built for the purpose of retaining the fill of an artificial platform.

Garlake (1970) produced one of the most useful typologies of the Zimbabwe culture dry-stone walls. His various subclasses (styles I, II and III) collapse into two major geographical variants. There is the southwestern Zimbabwe, northeastern Botswana and northern South Africa cluster or style III, dominated by terraced platforms belonging to the Leopard's Kopje and Khami periods. Examples of Leopard's Kopje sites with terraced walls include Mapungubwe Hill, Mapela Hill and others such as Malumba. These walls are indistinguishable from those of Khami-type sites such as Khami itself, Naletale, Taba Zika Mambo, Danamombe and many others (Robinson 1959, 1985; Summers 1965; Huffman 1996). The freestanding walls are rare in this cluster. The second cluster (styles I and II) is dominated by freestanding walls which form enclosures where houses of the elites were built. The freestanding walls are mostly decorated with

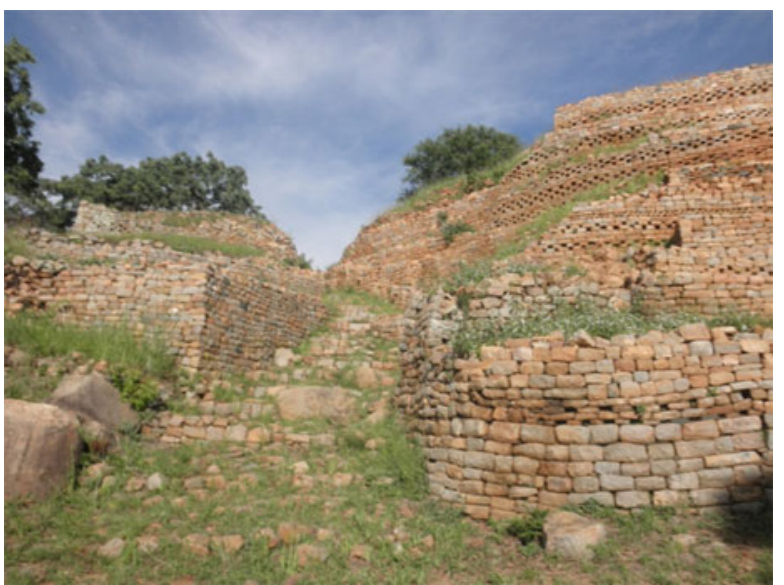

Fig. 5 Retaining walls on the Hill complex at Khami. Note the multiple bands of check decoration (photo: W. Ndoro) 


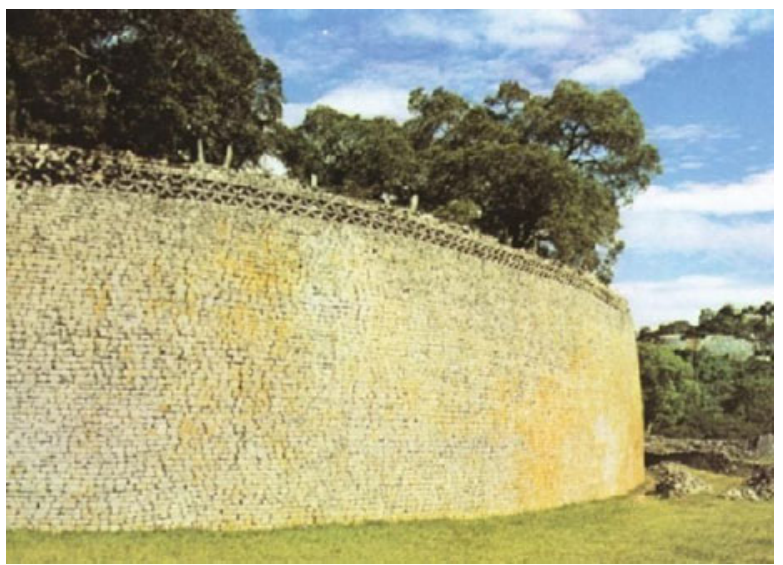

Fig. 6 Example of freestanding walls at Great Zimbabwe, the outer curtain wall of the Great Enclosure. Note the chevron pattern at top (photo: I. Pikirayi)

chevron designs and thus contrast with the check-decorated terraced platforms. Garlake (1970) suggested that the distribution of the stone wall types follows ethnic lines. The

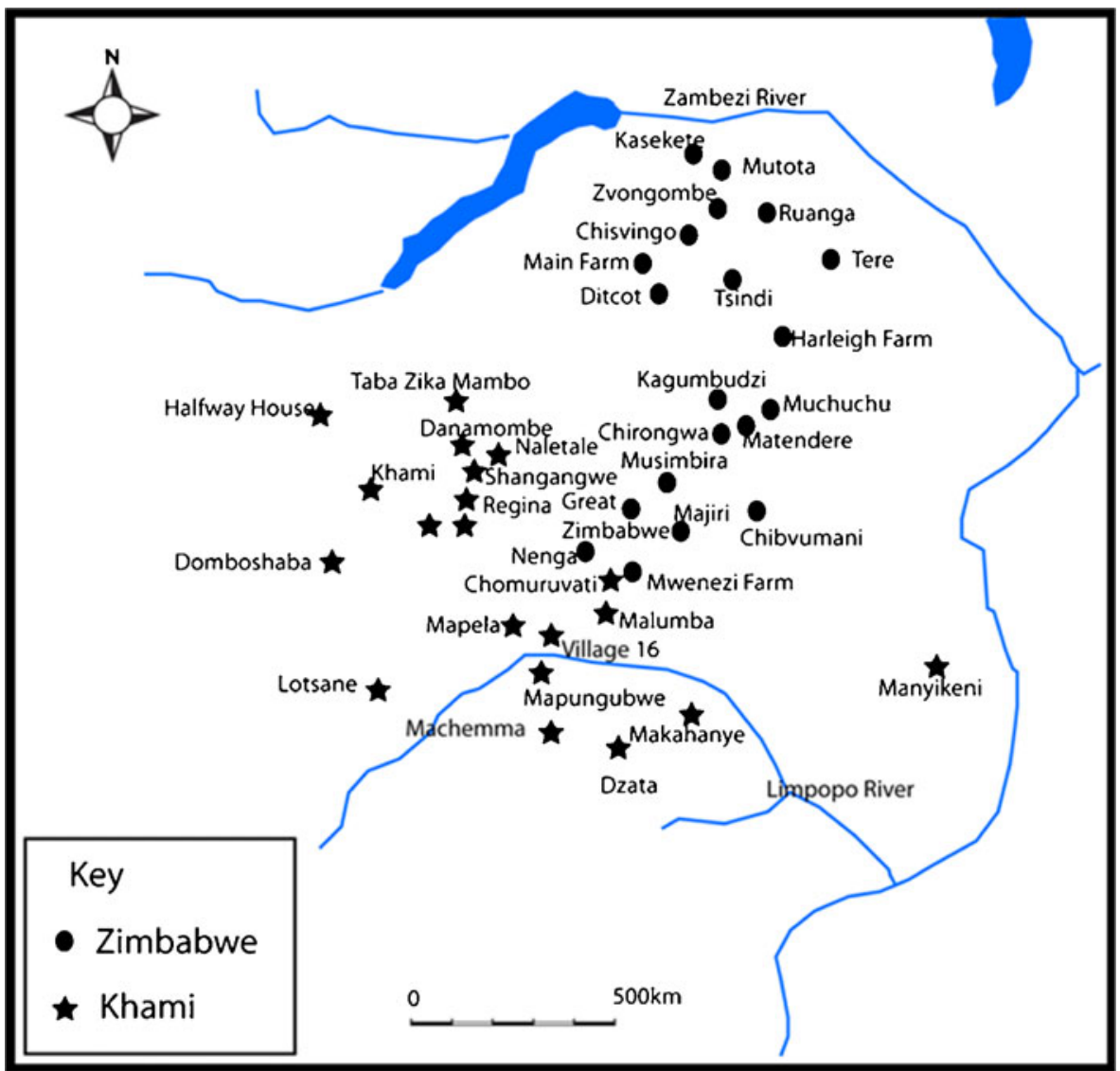

Fig 7 Approximate distribution of Zimbabwe culture walls in southern Africa, after Garlake (1970). Stars are retaining walls of Leopard's Kopje/Khami, while dots are freestanding walls 
terrace walls dominate the Leopard's Kopje-Khami-Kalanga area (southwestern Zimbabwe, northeastern Botswana and adjacent parts of northern South Africa). On their part, freestanding walls are mostly common in the south central, northern and eastern parts and adjacent areas (Fig. 7). Thus, they correspond to the distribution of the GumanyeGreat Zimbabwe-Karanga cluster.

What, therefore, is the earliest style of stone walling? According to Huffman (1982), Mapungubwe has the Zimbabwe culture's earliest stone wall atop the hill representing the region's first palace. This suggestion, however, requires careful consideration of the situation on the ground. Robinson (1965:7) has convincingly demonstrated that late first-millennium AD Zhizo and Leopards' Kopje phase I sites (Mambo and K2) are invariably associated with low stone walling or terracing. The scale of these walls increases during phase II (Mapungubwe and Woolandale) of Leopard's Kopje with rough stone walling being universal. In some cases such as Mapela and Mapungubwe, some terraces were well dressed and were used as revetment walls for building platforms for houses (Garlake 1970; Robinson 1985). Radiocarbon dates from undisturbed contexts at Nali Hill, a phase 2 Leopard's Kopje site, shows that it either overlaps or predates Mapungubwe (Robinson 1985). The tradition of building neatly dressed terraces was elaborated during the later Leopard's Kopje and Khami periods, such that the walls from Khami itself and related places such as Naletale were impressively dressed and decorated with check and other patterns. There is, however, a mismatch in knowledge regarding early stone walls of the Leopard's Kopje when compared to Gumanye. The Leopard's Kopje and Zhizo sites are mostly distributed around Bulawayo where archaeologists such as Robinson were based, and as a result, we know more about this area. Gumanye sites are only known from a few places that surround Great Zimbabwe and at places such as Gweru Kopje. Stone walling was observed at the Gumanye site of Chivowa although the association has not been considered in detail (Sinclair 1987). However, it is possible that some of the earliest stone walls on the hill at Great Zimbabwe were built during this period (Robinson 1985; Chipunza 1994; Chirikure et al. 2013).

Another important but related variable is that most Gumanye and Leopard's Kopje sites assume a hilly location. Hilly or hilltop locations are generally associated with leaders and positions of power. A literature survey indicated that most pre-K2/Mapungubwe Zhizo, Leopard's Kopje and Gumanye sites were either located on hilltops or on raised ground (Robinson 1965; Denbow et al. 2008). Some of them, for example Malumba (Manyanga et al. 2000) and Mapela, have evidence of occupation on flat areas and on raised ground, while others have evidence of occupation inside the enclosures and outside them. More importantly, the material culture used by residents of the hilltops was more or less identical to that of the occupants of the flat areas at places such as Mapungubwe and Great Zimbabwe (Caton-Thompson 1931; Summers et al. 1961; Meyer 1998). Given that hilltops such as Toutswe, Zimbabwe Hill, Mapela, Malumba, Leopard's Kopje, Zhizo Hill and many others have evidence of prestige goods in the form of glass beads, it becomes clear that they were also economically and politically important. This indicates that the idea of elite occupation on hilltops may have been on the landscape much more broadly and, in some cases, earlier than Mapungubwe. Another important point is that there are other places such as Mutota's Zimbabwe and Ngome Hill that were walled but located on level ground, despite the existence of hilltops nearby (Pikirayi 1993; Pwiti 1996) suggesting that hilltop location should not be the only important variable in determining the significance of a place and whether class distinction was present. Given that the Kalanga and Karanga were part of the 
Shona people who share the same worldview, it is difficult to understand why the preMapungubwe walling on raised ground would not have been associated with the majesty of kingship. It therefore appears that Mapungubwe was rather late in embracing this new ideology given that hilltop settlements with walls and prestige goods existed before it (Robinson 1965, 1985; Manyanga et al. 2000; Manyanga 2001).

\section{Bayesian Modelling of Zimbabwe Culture Radiocarbon Dates}

So far, the story from local material culture has highlighted a partitioning of Zimbabwe culture ceramics and walls along the Kalanga-Karanga axis. It is now important to consider radiocarbon evidence. Radiocarbon dating played an important role in building interpretations of the Zimbabwe culture. The whole idea about cultural precedence in the Shashi-Limpopo is anchored on the premise that Mapungubwe (AD 1220-1290) is the earliest Zimbabwe palace on a hill that demonstrates evidence of class distinction (Huffman 1982, 1996, 2000, 2007). Great Zimbabwe (AD 1300-1450) was the inheritor of the tradition after Mapungubwe's relapse. Around AD 1450, Khami succeeded Great Zimbabwe after the latter's decline (Pikirayi 2001; Huffman 2009). However, a reevaluation of the available radiocarbon dates using widely respected Bayesian modelling revealed a completely different picture where Mapungubwe and Great Zimbabwe overlap in the thirteenth and fourteenth centuries, while Khami seemed to flourish well before AD 1450 (see Chirikure et al. 2012, 2013).

A desktop search of the published dates for sites associated with the beginning, blossoming and relapsing of Zhizo, Leopard's Kopje, Gumanye, Zimbabwe and Khami sites was carried out. Attention was placed on the stratigraphic relationships between the contexts where the dates were derived. The materials that were dated vary from site to site but range from wood charcoal to carbonized seeds, charred bone and carbonized posts. In some cases, only a few dates were available with no stratigraphic relationships provided. The dated material is often presented as charcoal without elaborating whether it is from long- or short-lived samples. Furthermore, there are some inconsistencies that must be considered. For example, the archaeology of Great Zimbabwe has period II material culture, the equivalent of K2, but no dates are available (Huffman and Vogel 1991; Chirikure et al. 2013). Equally, the top sections of the stratigraphy have been destroyed by early excavators without record, so no dates are available. These legacies affect our current understanding of the regional radiocarbon chronology (see Chirikure et al. 2012).

The major advantage of Bayesian modelling is that it combines preexisting information with radiocarbon dates to generate modelled dates through likelihood estimation (Buck et al. 1991). The collected dates were fed into the program OxCal version 4 (Bronk Ramsey 1994, 1995, 2009) using the calibration curve for the southern hemisphere (McCormac et al. 2004) at the Research Laboratory for Archaeology and the History of Art, University of Oxford, by Mark Pollard. To begin with, Bayesian models were created for the individual sites factoring in the generally accepted phases at the sites (Chirikure et al. 2012). For example, at Mapungubwe, the following phases were noted: K2, Transitional K2 and Mapungubwe. Finally, the dates for all sites were combined into a single model that declared all phases equal, i.e., without declaring which site is earlier than the others. The results are shown in Fig. 8. 


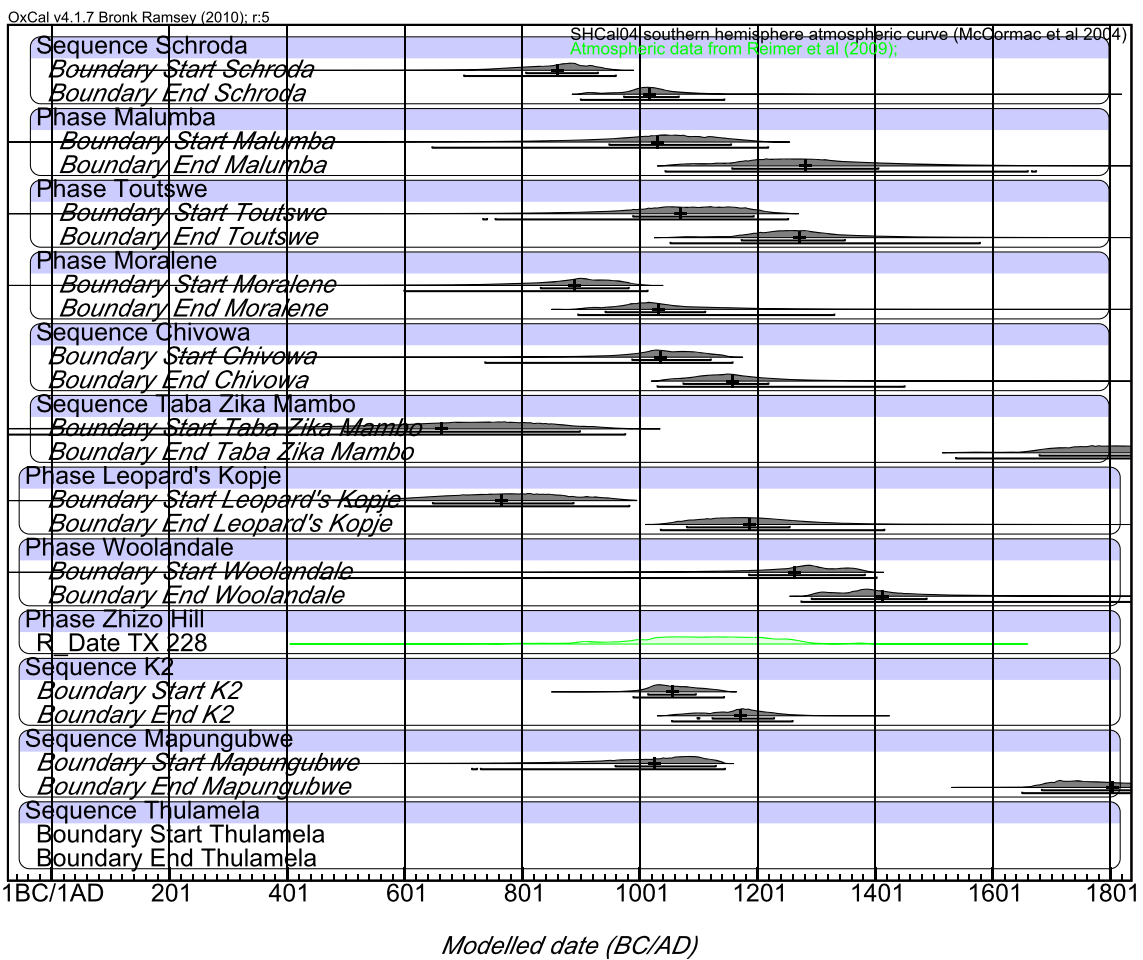

Fig. 8 The modelled dates for selected elite sites in southern Africa

The modelled dates provided some refreshing perspectives on the relationships between numerous late first- and early second-millennium $\mathrm{AD}$ sites in southern Africa. Figure 8 shows that Zhizo sites in southwestern Zimbabwe and northeastern Botswana are much earlier when compared to those in the Limpopo Depression. Furthermore, it shows that Zhizo communities occupied sites such as Toutswe into the thirteenth century. This observation is important because it was once suggested that Zhizo people moved out of the Shashi-Limpopo and settled in northeastern Botswana. The long sequence at places such as Bosutswe, Taukome and other sites questions this migrationist thinking. The same situation existed at places such as Taba Zika Mambo that have Zhizo, Leopard's Kopje and Khami material culture. Robinson (1985) actually argues for a relationship between Zhizo and Mambo which contradicts the concept of a northward migration of Shona people from $\mathrm{AD} 1000$, thereby questioning the way southern African archaeologists explain continuity and change in ceramic units. Calabrese (2007) has demonstrated that Zhizo people may not have left the middle Limpopo but instead existed alongside Leopard's Kopje people. More importantly, the dates for Malumba, Mapungubwe, Chivowa and Mapela overlap as they straddle the late first-millennium and early second-millennium $\mathrm{AD}$ interface (see Fig. 8). As mentioned earlier, these sites are located on hilltops and exhibit identical cultural attributes such as participation in long-distance trade.

The modelled chronology further indicates that Mapungubwe, Great Zimbabwe and places such as Tsindi and Harleigh Farm were overlapping (see Fig. 8). For Mapungubwe, occupation on the Hill and Mapungubwe Southern Terrace seem to relapse in the fourteenth century. This also supports the conclusion made by Prinsloo and Colomban (2008) on the 
basis of a Raman spectrometric study of Chinese porcelain from the hill. Then there are a number of Khami sites such as Khami itself, Domboshaba and others that flourished from the early fourteenth century AD onwards. Taba Zika Mambo is an interesting case because it also has a Zhizo occupation and a Leopard's Kopje component, which is directly succeeded by a Khami occupation (Robinson 1965). It is clear from the modelled dates that Khami was established long before Great Zimbabwe relapsed and possibly when Mapungubwe was still occupied. Zvongombe and Nhunguza, which are associated with the extension of the Zimbabwe culture into northern Zimbabwe, were established towards the end of Great Zimbabwe's flourishing. It seems that the development of the Zimbabwe culture in the north was achieved when Great Zimbabwe was still occupied. These data show that it is not prudent to consider Khami as an important place only after Great Zimbabwe was abandoned; it was on the landscape much earlier.

Of course, issues still require attention regarding the radiocarbon chronology, but there are strong indicators that Mapungubwe overlapped with numerous sites that exhibit similar cultural attributes and material culture (Chirikure et al. 2012, 2013). A succession of Zhizo sites seem to have flourished from about $\mathrm{AD} 800$ until the thirteenth century in southwestern Zimbabwe and northeastern Botswana (see also Denbow et al. 2008, fig. 8). Some of these sites had glass beads and were located on hilltops with accompanying settlement on the flats, indicating some hierarchy and social differentiation (Pwiti 1996). The same observation applies to the many Leopard's Kopje and Gumanye sites widely scattered in the region. Therefore, it is unlikely that only one place was associated with the development of complexity in southern Africa. Across space and time, numerous places were widely separated and exhibited identical cultural traits. It is also not clear from well-accepted explanations how the elites based at places such as Mapungubwe and Great Zimbabwe would have established and maintained their hegemony over vast areas involving hundreds of kilometres. It seems that the sociopolitical organization of major Shona subgroups such as Karanga and Kalanga started to evolve towards complexity from the late first millennium AD, resulting in the establishment of early states at Mapela, Mapungubwe, Zimbabwe Hill, Khami and other sites (see Beach 1984:38; Soper 1990; Pwiti 1996). Thus, the dating evidence as well as the ceramics and stone walling is pointing to the multiple trajectories that the development of sociopolitical complexity may have taken.

\section{Discussion: Towards a New Framework for Zimbabwe Culture Archaeology}

Tying together the evidence from local ceramics, stone architecture and Bayesian modelling, a number of statements can be made on the evolution of sociopolitical complexity and the development of the Zimbabwe culture. The first is that there seem to be major differences between the local ceramics at K2/Mapungubwe and Great Zimbabwe. Khami seems to be related more closely to Mapungubwe than to Great Zimbabwe. The evidence for this comes from the ceramics as well as the stone architecture. For local ceramics, the differences appear mostly in vessel shapes, and decoration techniques and placement. The ceramics from K2 and Mapungubwe are all lavishly decorated with incisions that often form arcades and triangles (Schofield 1937; Manyanga 2006; Huffman 2007). In contrast, pottery from periods II to IV at Great Zimbabwe is decorated hardly at all, and there is continuity in shape forms, decoration placement and techniques through time (Robinson 1961b; Chirikure et al. 
2013). While this contrast is remarkable, there is a striking resemblance between Mapungubwe pottery and the Leopard's Kopje ceramics in southwestern Zimbabwe and northeastern Botswana (Robinson 1965; Denbow et al. 2008). This distribution corresponds to the geographical concentration of Kalanga and Karanga speakers. More interestingly, there are strong similarities between Leopard's Kopje and Khami ceramics in terms of lavish designs and vessel shapes and types such as beakers, but more empirical work is required.

Evidence from stone walling also indicates major differences between Mapungubwe, Great Zimbabwe and Khami. The stone walls of Mapungubwe and other Leopard's Kopje sites are mostly retaining walls, some of which are decorated with the check pattern (Garlake 1970). These retaining walls seem to be prototypes of the platforms of Khami, the only difference being that of scale. The walling at Khami-type sites such as Domboshaba and Khami itself is far more extensive and elaborate (Robinson 1959). This again contrasts with Great Zimbabwe and related sites that are dominated by freestanding walls with chevron designs (Garlake 1970). Indeed, most dry-stone walls in central, northern and eastern Zimbabwe are all freestanding. The settlement preference of communities occupying these areas from the late first and early second millennium AD suggests that hilltops were preferred alongside flats during this time (see Table 1). Most Leopard's Kopje and Gumanye sites are located on hilltops, with Malumba having both a hilltop settlement and a seemingly contemporary occupation on the hill floor (Manyanga et al. 2000). As with Mapungubwe (Meyer 1998), the material culture of the hilltop and flat area is not substantially different. When placed within the context of ideology, it appears that the idea of class distinction evolved from the late first millennium $\mathrm{AD}$ and early second millennium AD. Given that Leopard's Kopje sites such as Nali Hill are earlier or contemporary with Mapungubwe (see also Robinson 1985), it becomes persuasive to argue that the Shashi-Limpopo was reflecting cultural developments that were taking place in the broader Shona world. There is no reason why hilltop occupations at Great Zimbabwe, Gweru Kopje and other places may not have been associated "with the majesty of kingship" in view of a shared worldview that the Shona people possessed.

In view of the major differences that exist between the Leopard's Kopje-Khami and Gumanye-Great Zimbabwe, the dating evidence is very important. The Bayesian modelling has suggested that most important sites overlap (for example Mapela, Mapungubwe, Malumba, Great Zimbabwe, etc.). The strong nature of these overlaps makes it difficult to sustain the argument that Mapungubwe had the Shona world's first palace. The modelled dates, however, indicate that Khami was an important place by the late thirteenth/early fourteenth century AD. It has been argued that Zhizo occupants of Schroda moved into northeastern Botswana to establish the Toutswe state. However, the dates from Zhizo sites in the area indicate continuity at places including Bosutswe. The dating evidence suggests that Zhizo communities were established in southwestern Zimbabwe and northeastern Botswana earlier than in the Shashi-Limpopo. Furthermore, these communities flourished well into the thirteenth century. As such, by focusing only on the Shashi-Limpopo, archaeologists in the process ignore the majority of sites on the landscape and that exhibit similar attributes. This biased perception should be balanced by redirecting attention to the core area and comparing the picture to what is happening at the edge (Shashi-Limpopo). Table 1 summarises the key features of sites from latefirst-millennium $\mathrm{AD}$ to second-millennium $\mathrm{AD}$ sites. 
Table 1 Key features of Zhizo, Leopard's Kopje, Khami, Great Zimbabwe and Mutapa sites

\begin{tabular}{|c|c|c|c|c|}
\hline Cultural tradition & Walling type & Local ceramics & $\begin{array}{l}\text { Settlement } \\
\text { location }\end{array}$ & Glass beads \\
\hline $\begin{array}{l}\text { Zhizo (cal AD 700-cal } \\
\text { AD 1250) }\end{array}$ & $\begin{array}{l}\text { Terrace walls? } \\
\text { (Leopard's Kopje main site) }\end{array}$ & Comb stamping, incisions, polychrome & $\begin{array}{l}\text { Near } \\
\text { hilltops, } \\
\text { on } \\
\text { hilltops }\end{array}$ & $\begin{array}{l}\text { Drawn translucent blue, green and yellow } \\
\text { beads }\end{array}$ \\
\hline $\begin{array}{l}\text { Leopard's Kopje (cal } \\
\text { AD 1000-cal AD } \\
1450 \text { ) }\end{array}$ & $\begin{array}{l}\text { Terraced walls (Mapungubwe, Mapela, } \\
\text { Malumba, Taba Zika Mambo) }\end{array}$ & $\begin{array}{l}\text { Incisions, graphite burnishing, polychrome } \\
\text { designs }\end{array}$ & $\begin{array}{l}\text { Flats, } \\
\text { hilltops }\end{array}$ & $\begin{array}{l}\text { Transparent to translucent blue-green to light } \\
\text { green beads, Garden Rollers, Indo-Pacific } \\
\text { beads, Mapungubwe oblates }\end{array}$ \\
\hline $\begin{array}{l}\text { Gumanye (cal AD } \\
1000-\mathrm{AD} 1250)\end{array}$ & $\begin{array}{l}\text { Low freestanding walls? (e.g., Chivowa, } \\
\text { Gumanye Hill, Great Zimbabwe) }\end{array}$ & $\begin{array}{l}\text { Incisions, occasional comb stamping, } \\
\text { graphite burnishing, rare polychrome }\end{array}$ & $\begin{array}{l}\text { Hilltops, } \\
\text { flats }\end{array}$ & $\begin{array}{l}\text { Transparent to translucent blue-green to light } \\
\text { green beads, Garden Rollers, Indo-Pacific } \\
\text { beads }\end{array}$ \\
\hline
\end{tabular}

(Sources: Robinson 1959, 1961a, b, c, 1965; Garlake 1968; Huffman 1974b; Pwiti 1996; Robertshaw et al. 2010, Wood 2011) 
The three core pillars of evidence considered so far indicate that Mapungubwe, Mapela, Great Zimbabwe and many other places overlap chronologically and that they share key cultural attributes. The distances between these places such as Mapungubwe and Great Zimbabwe or Mapungubwe and Taba Zika Mambo make it difficult to understand how one place would have maintained hegemony over another given limitations with logistics and travel at the time. Another category of evidence is the imports recovered from the early and later Zimbabwe culture sites. Locally, it is believed that imports such as glass beads were seen as prestige goods (Garlake 1973). Zhizo and pre-Mapungubwe Gumanye and Leopard's Kopje people participated in long-distance trade and exchange relationships as evidenced by the recovery of exotic goods such as glass beads (Wood 2012).

The earliest glass beads in southern Africa are known as Zhizo beads which were common from the ninth century $\mathrm{AD}$ onwards. Zhizo beads were recovered at multiple places in southwestern Zimbabwe, central Zimbabwe and northeastern Botswana (Robinson 1965; Denbow et al. 2008). These are followed by K2 series beads that were found at both Gumanye and Leopard's Kopje sites. K2 series are associated with the Garden Roller beads that occur at Leopards' Kopje sites such as K2 itself (Gardner 1963), Malumba (Manyanga et al. 2000) and at Great Zimbabwe (Robinson 1961c). Chronologically, K2 series are followed by Mapungubwe bead series which are dominated by black oblates. As with the K2 types, Mapungubwe series have a wide distribution at sites in southern Africa (Wood 2012). After Mapungubwe came the Great Zimbabwe series, difficult to distinguish from the Mapungubwe series (Robertshaw et al. 2010). Khami series replaced Great Zimbabwe-type beads from the fifteenth century. The major problem with existing works on beads from southern African sites is that rather than using the artefacts to establish independent chronological control over radiocarbon dating, all the researchers have pigeonholed bead types into the existing chronology. This is a fundamental flaw because the overlaps in the radiocarbon chronology of Mapungubwe and Great Zimbabwe may suggest that the black oblates were used during the same period, and with other bead types found from chronologically overlapping sites in the region (see Chirikure et al. 2013). Because they are chronological markers, the presence of different types of beads at places such as Great Zimbabwe indicates a long history of participation in international trade from K2 up to Khami times. Therefore, if the presence of imports shows the significance of a site, then Great Zimbabwe was important for this period (Wood 2011).

Wood (2012) studied the frequency of glass beads from commoner and elite sites in the Shashi-Limpopo and concluded that there is a small discrepancy in terms of quantities from domestic contexts. She suggested that access to beads may not have been under the control of a centralised authority. This has some support from historical accounts such as those by Mudenge (1988) that demonstrate that middlemen known as vashambadzi would travel from village to village bartering merchandise. Furthermore, young men of marriageable age would travel to look for chuma, or beads to give to the women they intended to marry (Bhila 1982). This tempers the thinking that capitals such as Mapungubwe and Great Zimbabwe monopolised all the trade. Even so, glass beads have a high frequency at commoner sites, posing questions over their role in societies - were they really prestige goods if, as Wood (2012) argues, they were found at both commoner and elite sites in comparable frequency? Only further research can tell.

Chinese celadon is one of the imported finds recovered from both Leopard's Kopje and Gumanye sites as well as the succeeding ones. However, since Garlake (1968), very few 
studies have engaged with this topic. Sung dynasty celadon was recovered from Mapungubwe, Khami (although unverified), Great Zimbabwe and the Marcadoni claims site near West Nicholson (Garlake 1968). In period IV levels at Great Zimbabwe, Persian faience and glass and Ming dynasty ceramics were also recovered (Caton-Thompson 1931; Garlake 1973; Collett et al. 1992). After the decline of Great Zimbabwe, imports continued to filter through into the interior at places such as Khami with finds of late Ming Dynasty porcelain, Portuguese imitations of Chinese porcelain and Indian beads. These imports are comparable to those of Zimbabwe tradition and Afro-Portuguese sites in the north including Dambarare, Baranda, Kasekete and Mutota (Pikirayi 1993).

However, our current knowledge of the imported ceramics requires updating, given that more is now known about Asian ceramics. A Raman spectrometric study of the chemical composition of the celadon recovered from Mapungubwe Hill compared its chemistry with that recorded in Chinese factories. The recipes revealed that the porcelain was manufactured in China from the fourteenth century onwards (Prinsloo and Colomban 2008; Prinsloo et al. 2011). This suggests that Mapungubwe may not have been abandoned by AD 1290 as currently believed. The same studies revealed that some of the porcelain from Great Zimbabwe was earlier than that from Mapungubwe. This indicates that the two places were flourishing at the same time and that because of its position in the interior, Great Zimbabwe may have accessed porcelains earlier than Mapungubwe.

Gold-working evidence has also been recovered from some of these sites stretching from northeastern Botswana to central Zimbabwe. The origins of gold production in southern Africa are associated with the integration of the region into the international trading system based at the Indian Ocean (Summers 1969). Not surprisingly, gold is seen as an elite metal associated with centres of power. Historical documents suggest that gold working in southern Africa started in the late first millennium AD, but little tangible evidence has been found (Summers 1969). It is currently not clear archaeologically when and where gold was first worked in the region, but gold objects were found at elite sites in northeastern Botswana, southwestern Zimbabwe and northern South Africa. There is a need for extensive research backed up by a robust dating programme to date the contexts where gold appears. The late first-millennium AD date makes a lot of sense given that gold was one of the commodities exchanged for glass beads, cloth and other exotic objects at the first- and second-millennium $\mathrm{AD}$ interface.

The combined material culture and radiocarbon dating evidence indicates that the current discussions about sociopolitical complexity and the Zimbabwe culture development oversimplify a complex situation. Perhaps, it is important to revisit the definition of sociopolitical complexity. It has been suggested that sociopolitical complexity in southern Africa began with the ideological transformations at K2 and that class distinction and sacred leadership crystallised at Mapungubwe. Mapungubwe is also viewed as an early state which makes it the region's first complex society. By comparison, it is important to consider definitions of sociopolitical complexity in other parts of the world. Carneiro (1967) argues that sociopolitical complexity encompasses hierarchically organized societies, developed chiefdoms and early states. The idea is that sociopolitically complex societies are ranked and have evidence of craft specialization and division of labour, advanced subsistence and economic systems, political organization, architecture, religion, writing and so on and so forth (Carneiro 1967; Renfrew and Cherry 1986). Thus, the Minoan polities, early Mayan city-states and the city-states of Sumer are some of the well-known examples that meet these criteria (Renfrew and Cherry 1986). 
The appropriateness of some of these indicators in non-western communities has been questioned by scholars such as Connah (1987) and McIntosh (1999). These scholars argue that a contextual approach is required to best understand African trajectories. Therefore, it is essential to provide a brief overview of the organization of southern African communities from the mid-first millennium AD to the early second millennium AD. Pwiti (1996) identified four stages of organization. During the first stage ( $c a$. AD 300 to 700), early farming communities occupied dispersed villages with no evidence of social differentiation and ranking. The second stage, extending from the seventh century $\mathrm{AD}$, coincides with the introduction of external trade. Archaeologically, we see a shift in production towards goods with exchange value (Pwiti 1996). The third stage, from about the ninth century AD, sees an increase in the volume of trade and is characterised by villages which begin to show evidence of social differentiation. The fourth and last stage then sees the establishment of state structures such as Mapungubwe, Mapela and Great Zimbabwe. Therefore, it is prudent to argue that sociopolitical complexity started from the eighth century $\mathrm{AD}$ as evidenced by multiple sites with evidence of glass beads, worked ivory, metalworking and stone wall construction. Therefore, from the last two centuries of the first millennium $\mathrm{AD}$, southern African communities were gravitating towards full sociopolitical complexity. Not surprisingly, the early second millennium AD saw the emergence of places which may be described as early states or chiefdoms. These include Mapela Hill, Mapungubwe, Zimbabwe Hill and others (see Beach 1984). The Bayesian modelling has indicated that these sites chronologically overlap, further showcasing that the developments were spread across the whole landscape and were not restricted only to the Shashi-Limpopo Valley.

Because distances of at least $100 \mathrm{~km}$ separate some of these polities, it is reasonable to assume that they were autonomous (Beach 1984:38; Huffman 2007). In this milieu, it can be argued that sociopolitical complexity emerged within the context of peer polity interaction as in many other places in the world. According to Renfrew and Cherry (1986:2), "peer polity interaction designates the full range of interchanges taking place (including imitation, emulation, cooperation, warfare and exchange of material goods and of information) between autonomous (i.e., self-governing and in that sense politically independent) socio-political units which are situated beside or close to each other within a single geographical region, or in some cases more widely." From the late first millennium AD, we see evidence of many polities, and by the early second millennium $\mathrm{AD}$, settlements are much bigger, while social differentiation becomes even more visible. Because places such as Mapela, Mapungubwe, Zimbabwe Hill, Nali Hill, Malumba and many others contain evidence of walling and exotic goods, it is reasonable to view them as peers and not as subordinates within the superstates of Mapungubwe, Khami or Great Zimbabwe. This explains why there are so many elite sites alongside Mapungubwe and Great Zimbabwe: Khami emerged when Great Zimbabwe was still at the height of its power because the latter did not have full control of the region. Apart from being backed up by realities in other parts of the world, this model fits closely Shona political and succession systems. Beach (1994) has demonstrated that some modern dynasties such as Buhera and Manyika have deep antecedents in their areas, to the extent that a settlement succession from the time of Great Zimbabwe's demise to the recent past can be reconstructed. Buhera has stone-walled sites, some with gold, whose pottery resembles that from Great Zimbabwe. Therefore, the idea of superstates is exaggerated; the political units were much smaller while political power rotated a number of centres creating a chain of capitals (Chirikure et al. 2012). It is not possible to measure chronologically the time when these places rotated power, given the 
limitation of radiocarbon dating, which pulls small events into bigger time periods. Even the historical Mutapa state was also associated with different centres of power and coexisted alongside autonomous polities such as the Changamire State. This makes it possible that most sites which are more than $100 \mathrm{~km}$ from places such as Great Zimbabwe, Khami or Mapungubwe may have been independent. Indeed, as discussed above, many of these exist. Otherwise, it is difficult to imagine how it would be possible administratively for one place to dominate tens of places that overlap with it chronologically and were situated in distant areas.

Against this background of peer polity interaction, the development of the Zimbabwe culture may not have followed a linear path but was more complex as dictated by specific political, economic and social conditions of the time. The late first- and early secondmillennium $\mathrm{AD}$ communities were more dynamic than we give them credit for. As such, the linear route that takes off from Mapungubwe via Great Zimbabwe to Khami is far away from the historical realities presented in historical accounts of Shona communities (see Beach 1980, 1984, 1994). Also, it is not clear from current discussions on sociopolitical complexity how control and power were exercised. Indeed, Kim and Kusimba's (2008) discussion of warfare and coercion as important variables is a refreshing one. Admittedly, people were not fighting all the time, but Changamire established his state based on conquest just as the Mutapas carried out wars to expand their territories (Pikirayi 1993). As such, more research and debate are required for us to understand the subject of sociopolitical complexity in a better way. It is difficult to find the first stone wall, the first gold object and the first stone palace, but it is possible to identify a suite of sites that show evidence of growing sociopolitical complexity in our region.

\section{Conclusion}

Without the contributions of previous researchers, our understanding of the development of the Zimbabwe culture would not have reached thus far. For purposes of this study, a wide array of data was marshalled to elicit a few salient conclusions on the development of sociopolitical complexity and the relationships between Mapungubwe, Great Zimbabwe and Khami. The first is that the elements of spatial organization attested at K2/Mapungubwe were already expressed within much of the landscape as attested at Zhizo and K2/Mambo sites in northeastern Botswana and southwestern Zimbabwe. Imports started to filter into the region from $\mathrm{AD} 800$, creating social differentiation and thereby placing the society on the path to sociopolitical complexity. Furthermore, the numbers of cattle also started to increase in size closer to $\mathrm{AD} 1000$. Not surprisingly, late first-millennium $\mathrm{AD}$ sites increasingly appear as vast villages on hilltops and flats. The second point is that in terms of local ceramics and stone walling, there are massive differences between Leopard's Kopje-Khami and Gumanye-Zimbabwe clusters which mimic the Karanga/Kalanga divide. Imported artefacts and gold were recovered from numerous sites coeval with Mapungubwe, suggesting that there was no central redistributing authority. Bayesian modelling indicates that Great Zimbabwe and Mapungubwe overlap chronologically for the early second millennium AD together with other sites. Also, Khami flourished earlier than the commonly agreed AD 1450 start date implies. Researchers have ignored the basal deposits at Khami which indicate an occupation that overlaps with Great Zimbabwe and Mapungubwe. Therefore, the many chronologically overlapping and widely separated sites that share attributes of stone walling, 
hilltop settlement, gold working and so on with Mapungubwe are likely competing and possibly fighting peers rather than provincial or district centres (Chirikure et al. 2012). Some of the distances between these sites (for example, $250 \mathrm{~km}$ between Mapungubwe and Great Zimbabwe) would have made administration cumbersome if not impossible. In fact, the idea of a super Mapungubwe state, a super Great Zimbabwe state and so on is at variance with how Shona political systems seem to have operated (Beach 1994; Chirikure et al. 2012). Finally, there is no doubt that most researchers of today rely on syntheses of syntheses. It is important to consult original excavation reports since some important observations may have fallen through the crevices during selection processes by researchers. Thirty years ago, Garlake (1982:3) challenged local archaeologists to come up with new ways of understanding the Zimbabwe culture and sociopolitical complexity. This paper is a response to that call; hopefully, more research will contribute to these debates.

Acknowledgments Financial support from the National Research Foundation of South Africa (Bluesky Research Grant: 85892) and the Programme for Enhancement of Research Capacity (PERC) of University of Cape Town Research Office is acknowledged with sincere gratitude. The research at Khami, Mapela and Great Zimbabwe was carried out under a permit from the National Museums and Monuments of Zimbabwe (NMMZ). We thank Dr. Mahachi, the Executive Director of NMMZ, for his generosity and goodwill. Our thanks also go to Simon Hall, Foreman Bandama, Abigail Moffett and two anonymous reviewers, who provided tremendous comments that enhanced the quality and scope of this paper. Special thanks also go to the editor, Adria LaViolette, for additional insights.

\section{References}

Beach, D. N. (1980). The Shona and Zimbabwe 900-1850. Gweru: Mambo Press.

Beach, D. N. (1984). Zimbabwe before 1900. Gweru: Mambo Press.

Beach, D. N. (1994). A Zimbabwean past: Shona dynastic histories and oral traditions. Gweru: Mambo Press.

Beach, D. N. (1998). Cognitive archaeology and the imaginary history of Great Zimbabwe. Current Anthropology, 39, 47-72.

Beach, D., Bourdillon, M. F. C., Denbow, J., Hall, M., Lane, P., Pikirayi, I., et al. (1997). Review feature: Snakes and crocodiles: Power and symbolism in ancient Zimbabwe, by Thomas N. Huffman. South African Archaeological Bulletin, 52(166), 125-138.

Bent, J. T. (1896). The ruined cities of Mashonaland: Being a record of excavation and exploration in 1891. Green: Longmans.

Bhila, H. H. K. (1982). Trade and politics in a Shona kingdom: The Manyika and their African and Portuguese neighbours, 1575-1902. Essex: Longman, Harlow.

Bronk Ramsey, C. (1994). Analysis of chronological information and radiocarbon calibration: The program OxCal. Archaeological Computing Newsletter, 41, 11-16.

Bronk Ramsey, C. (1995). Radiocarbon calibration and analysis of stratigraphy: The OxCal program. Radiocarbon, 37(2), 425-430.

Bronk Ramsey, C. (2009). Bayesian analysis of radiocarbon dates. Radiocarbon, 51(1), 337-360.

Buck, C. E., Kenworthy, J. B., Litton, C. D., \& Smith, A. F. M. (1991). Combining archaeological and radiocarbon information: A Bayesian approach to calibration. Antiquity, 65, 808-821.

Calabrese, J. A. (2007). The emergence of social and political complexity in the Shashi-Limpopo Valley of Southern Africa, AD 900 to 1300: Ethnicity, class, and polity (Vol. 1617). British Archaeological Reports Ltd.

Carneiro, R. L. (1967). On the relationship between size of population and complexity of social organization. Southwestern Journal of Anthropology, 23(3), 234-243.

Caton-Thompson, G. (1931). The Zimbabwe Culture: Ruins and reactions. Oxford: Clarendon.

Caton-Thompson, G. (1939). Mapungubwe. I. The excavations and culture. Antiquity, 13(51), 324-341.

Chipunza, K. T. (1994). A diachronic analysis of the architecture of the Hill Complex at Great Zimbabwe. Uppsala: Societas Archaeologica Upsaliensis. 
Chirikure, S., \& Pikirayi, I. (2008). Inside and outside the dry stone walls: Revisiting the material culture of Great Zimbabwe. Antiquity, 82, 976-993.

Chirikure, S., Manyanga, M., \& Pollard, A. M. (2012). When science alone is not enough: Radiocarbon timescales, history, ethnography and elite settlements in southern Africa. Journal of Social Archaeology, 12(3), 356-379.

Chirikure, S., Pikirayi, I., \& Pwiti, G. (2001). A comparativer study of Khami pottery Zimbabwe. In G. Pwiti \& F. Chami (Eds.), Southern Africa and the Swahili World (pp. 121-135). Dar es Salam: Dar es Salam University Press.

Chirikure, S., Pollard, A. M., Manyanga, M., \& Bandama, F. (2013). A Bayesian chronology of Great Zimbabwe: Re-threading the sequence of a vandalized monument. Antiquity, 87(337), $854-872$.

Collett, D. P., Vines, A. E., \& Hughes, E. G. (1992). The chronology of the Valley Enclosures: Implications for the interpretation of Great Zimbabwe. African Archaeological Review, 10(1), 139-161.

Connah, G. (1987). African civilisations. Precolonial cities and states in tropical Africa: An archaeological perspective. Cambridge: Cambridge University Press.

DEAT. (2002). Mapungubwe nomination dossier. South Africa: Government Printer.

Denbow, J., Smith, J., Ndobochani, N. M., Atwood, K., \& Miller, D. (2008). Archaeological excavations at Bosutswe, Botswana: Cultural chronology, paleo-ecology and economy. Journal of Archaeological Science, 35(2), 459-480.

Fontein, J. (2006). The silence of Great Zimbabwe: Contested landscapes and the power of heritage. Cavendish Pub Ltd.

Fouché, L. (1937). Mapungubwe. Cambridge: Cambridge University Press.

Galloway, A. (1963). The skeletal remains of Mapungubwe. In L. Fouché (Ed.), Mapungubwe. Cambridge: Cambridge University Press

Gardner, G. A. (1955). Mapungubwe 1935-1940. The South African Archaeological Bulletin, 10(39), $73-77$.

Gardner, G. A. (1963). Mapungubwe, Vol. II. Pretoria: J.L. Van Schaik.

Garlake, P. S. (1968). The value of imported ceramics in the dating and interpretation of the Rhodesian Iron Age. Journal of African History, 9(1), 13-33.

Garlake, P. S. (1970). Rhodesian ruins - A preliminary assessment of their styles and chronology. Journal of African History, 11(4), 495-513.

Garlake, P. S. (1973). Great Zimbabwe. London: Thames \& Hudson.

Garlake, P. S. (1978). Pastoralism and Zimbabwe. Journal of African History, 19(4), 479-93.

Garlake, P. S. (1982). Prehistory and ideology in Zimbabwe. Africa: Journal of the International African Institute, 52(3), 1-19.

Hall, M. (1984). The burden of tribalism: The social context of southern African Iron Age studies. American Antiquity, 49(3), 455-467.

Hall, M. (1987). The changing past. Cape Town: David Philip.

Hall, M. (1990). Hidden history: Iron Age archaeology in Southern Africa. In P. Robertshaw (Ed.), $A$ history of African archaeology (pp. 59-77). London: James Currey.

Hall, M. (2009). New knowledge and the university. Anthropology Southern Africa, 32(1/2), 69-76.

Hall, M., \& Vogel, J. C. (1980). Some recent radiocarbon dates from southern Africa. Journal of African History, 21(4), 431-55.

Hall, R. N., \& Neal, W. G. (1902). The ancient ruins of Rhodesia. London: Methuen.

Huffman, T. N. (1974a). Linguistic affinities of the Iron Age in Rhodesia. Arnoldia, 8(23), 1-12.

Huffman, T. N. (1974b). The Leopard's Kopje tradition (No. 6). Salisbury: Trustees of the National Museums and Monuments of Rhodesia.

Huffman, T. N. (1978). The origins of Leopard's Kopje: An 11th century difaquane. Zimbabwe: National Museums and Monuments of Rhodesia.

Huffman, T. N. (1980). Ceramics, classification and Iron Age entities. African Studies, 39(2), 123-174.

Huffman, T. N. (1982). Archaeology and ethnohistory of the African Iron Age. Annual Review of Anthropology, $11,133-150$.

Huffman, T. N. (1996). Snakes and crocodiles: Power and symbolism in ancient Zimbabwe. Johannesburg: Witwatersrand University Press.

Huffman, T. N. (2000). Mapungubwe and the origins of the Zimbabwe Culture. In M. Leslie \& T. Maggs (Eds.), African naissance: The Limpopo Valley 1000 years ago (pp. 14-29). South African Archaeological Society: Vlaeberg.

Huffman, T. N. (2007). Handbook to the Iron Age: The archaeology of pre-colonial farming societies in Southern Africa. Scottsville: University of KwaZulu-Natal Press.

Huffman, T. N. (2009). Mapungubwe and Great Zimbabwe: The origin and spread of social complexity in southern Africa. Journal of Anthropological Archaeology, 28, 37-54. 
Huffman, T. N., \& Vogel, J. C. (1991). The chronology of Great Zimbabwe. South African Archaeological Bulletin, 46, 61-70.

Jaffey, A. J. E. (1966). A reappraisal of the history of the Rhodesian Iron Age up to the fifteenth century. The Journal of African History, 7(2), 189-195.

Killick, D. (2009). Agency, dependency, and long-distance trade: East Africa and the Islamic world, ca. 7001500 CE. In S. E. Falconer \& C. L. Redman (Eds.), Polities and power: Archaeological perspectives on the landscapes of early states (pp. 179-207). Tucson: University of Arizona Press.

Kim, N., \& Kusimba, C. (2008). Pathways to social complexity and political centralization in the southern Zambezian region. African Archaeological Review, 25, 131-152.

Kuper, A. (1982). Wives for cattle: Bridewealth and marriage in southern Africa. London: Routledge \& Kegan Paul.

Kusimba, C. (2006). Slavery and warfare in African chiefdoms. In E. Arkush \& M. Allen (Eds.), The archaeology of warfare: Prehistories of raiding and conquest (pp. 214-249). Gainesville: University Press of Florida.

Lane, P. J. (1994). The use and abuse of ethnography in the study of the southern African Iron Age. Azania, 29/30, 51-64.

Lane, P. J. (2005). Barbarous tribes and unrewarding gyrations? The changing role of ethnographic imagination. In A. B. Stahl (Ed.), African archaeology. A critical introduction (pp. 24-54). London: Blackwell.

Lane, P. (2011). Possibilities for a postcolonial archaeology in sub-Saharan Africa: Indigenous and usable pasts. World Archaeology, 43(1), 7-25.

MacIver, D. (1906). Medieval Rhodesia. London: Routledge.

Manyanga, M. (2001). Choices and constraints: Animal resource exploitation in southeastern Zimbabwe. Uppsala: Societa Archaeologica Uppsaliensis.

Manyanga, M., Pikirayi, I., \& Ndoro, W. (2000). Coping with dryland environments: Preliminary results from Mapungubwe and Zimbabwe phase sites in the Mateke Hills, south-eastern Zimbabwe. South African Archaeological Society, Goodwin Series, 8, 69-77.

McCormac, F. G., Hogg, A. G., Blackwell, P. G., Buck, C. E., Higham, T. F. G., \& Reimer, P. J. (2004). SHCAL04 Southern hemisphere calibration, 0-11.0 cal Kyr BP. Radiocarbon, 46, 1087-1092.

McIntosh, S. K. (Ed.). (1999). Beyond chiefdoms: Pathways to complexity in Africa. Cambridge: Cambridge University Press.

Meyer, A. (1998). The archaeological sites of Greefswald. Pretoria: University of Pretoria.

Mudenge, S. I. (1988). A political history of Munhumutapa c 1400-1902. Harare: Zimbabwe Publishing House.

Pikirayi, I. (1993). The archaeological identity of the Mutapa state: Towards an historical archaeology of northern Zimbabwe. Uppsala: Societas Archaeologica Upsaliensis.

Pikirayi, I. (2001). The Zimbabwe Culture: Origins and decline of southern Zambezian states. Walnut Creek: AltaMira.

Prinsloo, L. C., \& Colomban, P. (2008). A Raman spectroscopic study of the Mapungubwe oblates: Glass trade beads excavated at an Iron Age archaeological site in South Africa. Journal of Raman Spectroscopy, 39(1), 79-90.

Prinsloo, L. C., Tournié, A., \& Colomban, P. (2011). A Raman spectroscopic study of glass trade beads excavated at Mapungubwe Hill and K2, two archaeological sites in southern Africa, raises questions about the last occupation date of the hill. Journal of Archaeological Science, 38, 3264-3277.

Pwiti, G. (1991). Trade and economies in southern Africa: The archaeological evidence. Zambezia, 18(2), 119-129.

Pwiti, G. (1996). Peasants, chiefs and kings: A model of the development of cultural complexity in northern Zimbabwe. Zambezia, 23, 31-52.

Renfrew, C., \& Cherry, J. (1986) Peer polity interaction and socio-political change. In R. Preucel \& I. Hodder (Eds.), Contemporary archaeology in theory: A reader (pp. 114-142). Oxford: Blackwell.

Robertshaw, P., Wood, M., Melchiorre, E., Popelka-Filcoff, R., \& Glascock, M. D. (2010). Southern African glass beads: Chemistry, glass sources and patterns of trade. Journal of Archaeological Science, 37, 1898-1912.

Robinson, K. R. (1959). Khami ruins. Cambridge: Cambridge University Press.

Robinson, K. (1961a). Excavations on the Acropolis Hill. Occasional Papers of the National Museums of Rhodesia, 3(23A), 159-192.

Robinson, K. (1961b). Zimbabwe pottery. Occasional Papers of the National Museums of Rhodesia, $3(23 \mathrm{~A}), 193-226$.

Robinson, K. (1961c). Zimbabwe beads. Occasional Papers of the National Museums of Rhodesia, 3(23A), 227-229.

Robinson, K. R. (1965). The Leopard's Kopje culture: A preliminary report on recent work. Arnoldia, 25, 1-7.

Robinson, K. R. (1985). Dated Iron Age sites from the upper Umguza Valley 1982: Their possible implications. South African Archaeological Bulletin, 40(141), 17-38.

Schmidt, P. R. (Ed.). (2009). Postcolonial archaeologies in Africa. Santa Fe: School for Advanced Research.

Schofield, J. F. (1937). The pottery of the Mapungubwe district. In L. Fouché (Ed.), Mapungubwe. Cambridge: Cambridge University Press. 
Sinclair, P. J. J. (1987). Space, time and social formation: A territorial approach to the archaeology and anthropology of Zimbabwe and Mozambique c 0-1700 AD. Uppsala: Societas Archaeologica Upsaliensis.

Soper, R. (1990). Great Zimbabwe tradition in local context. In P. Sinclair \& G. Pwiti (Eds.), Urban origins in Eastern Africa: Proceedings of the 1990 Workshop, Harare and Great Zimbabwe. Stockholm: Central Board on Antiquities.

Summers, R. (1965). Zimbabwe: A Rhodesian mystery. Johannesburg: Nelson.

Summers, R. (1969). Ancient mining in Rhodesia and adjacent areas. Salisbury: Trustees of the National Museums of Rhodesia.

Summers, R., \& Whitty, A. (1961). The development of the Great Enclosure. Occasional Papers of the National Museums of Southern Rhodesia, 3(23A), 306-325.

Summers, R., Robinson, K., \& Whitty, A. (1961). Zimbabwe excavations. Occasional Papers of the National Museums of Rhodesia, 3(23A), 15-332.

van Riet Lowe, C. (1936). Mapungubwe. First report on excavations in the northern Transvaal. Antiquity, 10(39), 282-291.

Wood, M. (2011). A glass bead sequence for southern Africa from the 8 th to the 16 th century AD. Journal of African Archaeology, 9(1), 67-84.

Wood, M. (2012). Interconnections: Glass beads and trade in southern and eastern Africa and the Indian Ocean-7th to 16th centuries AD. Uppsala: Studies in Global Archaeology. 